\title{
Abiotic landscape and vegetation patterns in the Netherlands during the Weichselian Late Glacial
}

\author{
W.Z. Hoek ${ }^{1}$ \\ 1 The Netherlands Centre for Geo-ecological Research (ICG), Faculty of Earth Sciences, \\ Vrije Universiteit Amsterdam, De Boelelaan 1085, NL-1081 HV Amsterdam, \\ the Netherlands. \\ Present address: The Netherlands Centre for Geo-ecological Research (IGC), Faculty of \\ Geographical Sciences, Utrecht University, P.O. Box 80015, NL-3508TC UTRECHT, \\ the Netherlands; e-mail: w.hoek@geog.uu.nl
}

Manuscript received: 25 June1999; accepted in revised form: 14 February 2000

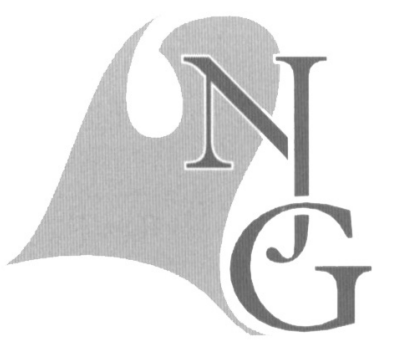

\begin{abstract}
The Late Glacial landscape of the Netherlands was a landscape with changing geomorphology and vegetation. Glacial, eolian and fluvial processes in the time before the Late Glacial initially had formed the main landscape types that still existed during the Late Glacial. In these landscape types, geomorphological processes persisted, particularly during intervals when the vegetation cover was discontinuous. Vegetation development initiated soil formation and stabilised the substratum. On the other hand, the abiotic landscape influenced vegetation development, and particularly vegetation patterns.

The Late Glacial vegetation patterns, changing in time, have been reconstructed on the basis of a palynological database containing the data from over 250 pollen diagrams from the Netherlands. Patterns of vegetation and abiotic landscape appear to compare to each other in many instances, indicating the close interrelationship between vegetation and the abiotic landscape.
\end{abstract}

Keywords: geomorphology, Late Glacial, palynology, paleogeography, the Netherlands

\section{Introduction}

The Weichselian Late Glacial forms the transition from the cold Pleniglacial to the warmer Holocene and is dated to between 13,000 and $10,000{ }^{14} \mathrm{C}$ years BP. Climate changes over this transition are recorded classically by palynological investigations. The changes in climate influenced the whole landscape. Not only vegetation changed, as reflected in numerous paleoecological studies, but the abiotic components of the landscape also reacted to the climatic changes.

From a geological point of view, changes in climate occurred very quickly. The mean July temperature rose by at least $5^{\circ} \mathrm{C}$ at the start of the Late Glacial, and marked changes in precipitation also seem to have occurred. At least one major temperature decline occurred during the Late Glacial, i.e., during the Younger Dryas stadial, when the temperature dropped to such an extent that both vegetation and the abiotic landscape changed considerably. It might be expected that only minor spatial differences in climate would then have occurred in The Netherlands, because of the small area and relatively large distance to the former coastline (the sea level was over $90 \mathrm{~m}$ lower than today at the time). On the other hand, various landscape types were present that should have influenced vegetation. This implies that differences in vegetation patterns cannot be ascribed to spatial differences in climate, but must rather be related to the abiotic environment (Hoek, 1997a).

Changes in hydrology, geomorphological processes, and soil development led to changes in the abiotic landscape. These changes in the abiotic environment and vegetation are commonly considered separately but a close interrelationship must actually have existed. The changes of vegetation through time can be 
considered as changes in vegetation patterns, which varied within each individual type of abiotic landscape. By adopting a paleogeographical approach, vegetation patterns and changes in these patterns can be compared with geological or geomorphological maps. If the relationships between paleovegetation and the abiotic components of the landscape are known, the influence of the climate can be analysed more closely.

Some of the results of a larger research project (see also Hoek 1997c,d) are discussed in the present contribution. Vegetation patterns on a regional scale appear to be closely related to the abiotic landscape. The complex interrelationships between the abiotic landscape and vegetation, and particularly the influences of vegetation on geomorphological processes are, however, not the main subject of the present paper and will be discussed separately (Hoek, in prep.). It will be shown in the present contribution that the influence of the abiotic landscape on vegetation has to be taken into account, when interpreting climate/vegetation relationships.

\section{Methods}

By using a paleogeographical approach, the vegetation patterns and changes in these patterns can be compared with geological or geomorphological maps. This approach requires a dense network of palynological sites in an area with a well-known geology and geomorphology such as the Netherlands. Essential to the reconstruction of vegetation patterns through time is, however, a good age control on the individual pollen profiles.

\section{Vegetation development in time}

A considerable body of Late Glacial palynological data have been assembled from NW Europe and especially from the Netherlands during the last decades (Fig. 1). Most of these data are now available digital$1 y$, and the general vegetation development for this time-span is well known. The vegetation development in the Netherlands during the Late Glacial and Early Holocene has been described by several authors (among them Van der Hammen, 1951; Van Geel et al., 1989; Bohncke, 1993; Hoek, 1997b).

With the help of 239 radiocarbon dates derived from 102 pollen diagrams from the Netherlands, northern Belgium and western Germany, the general vegetation development has been linked to the uncalibrated radiocarbon time scale (Hoek, 1997b). The pollen diagrams in the database have been subdivided into zones and subzones (Fig. 2). Note that, for the

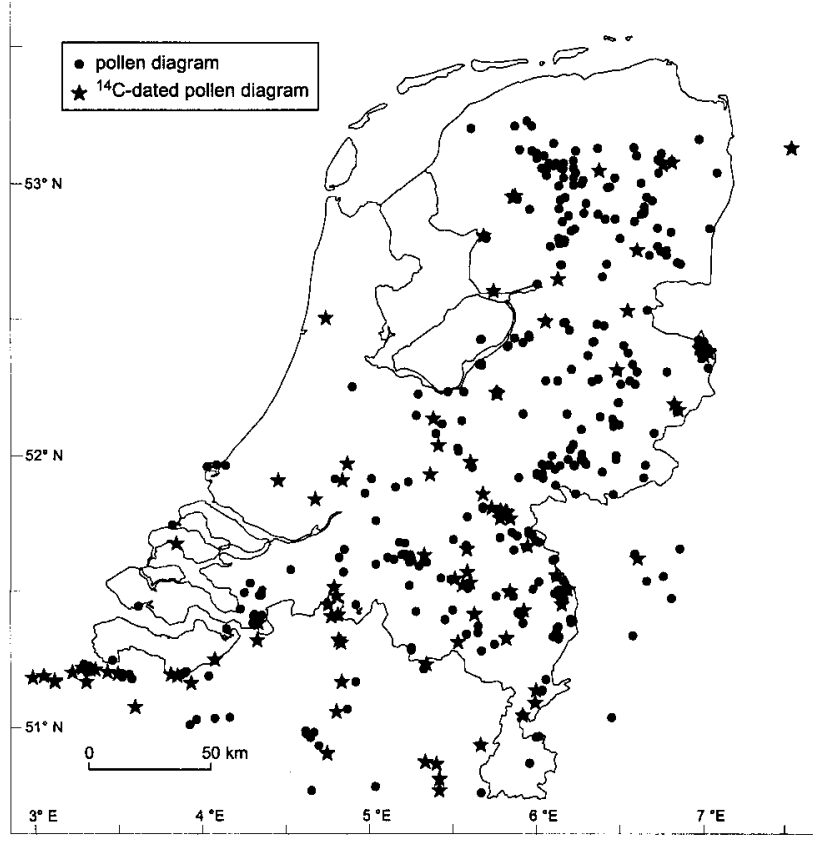

Fig. 1. Locations of palynologically investigated Late Glacial profiles in the Netherlands and direct surroundings.

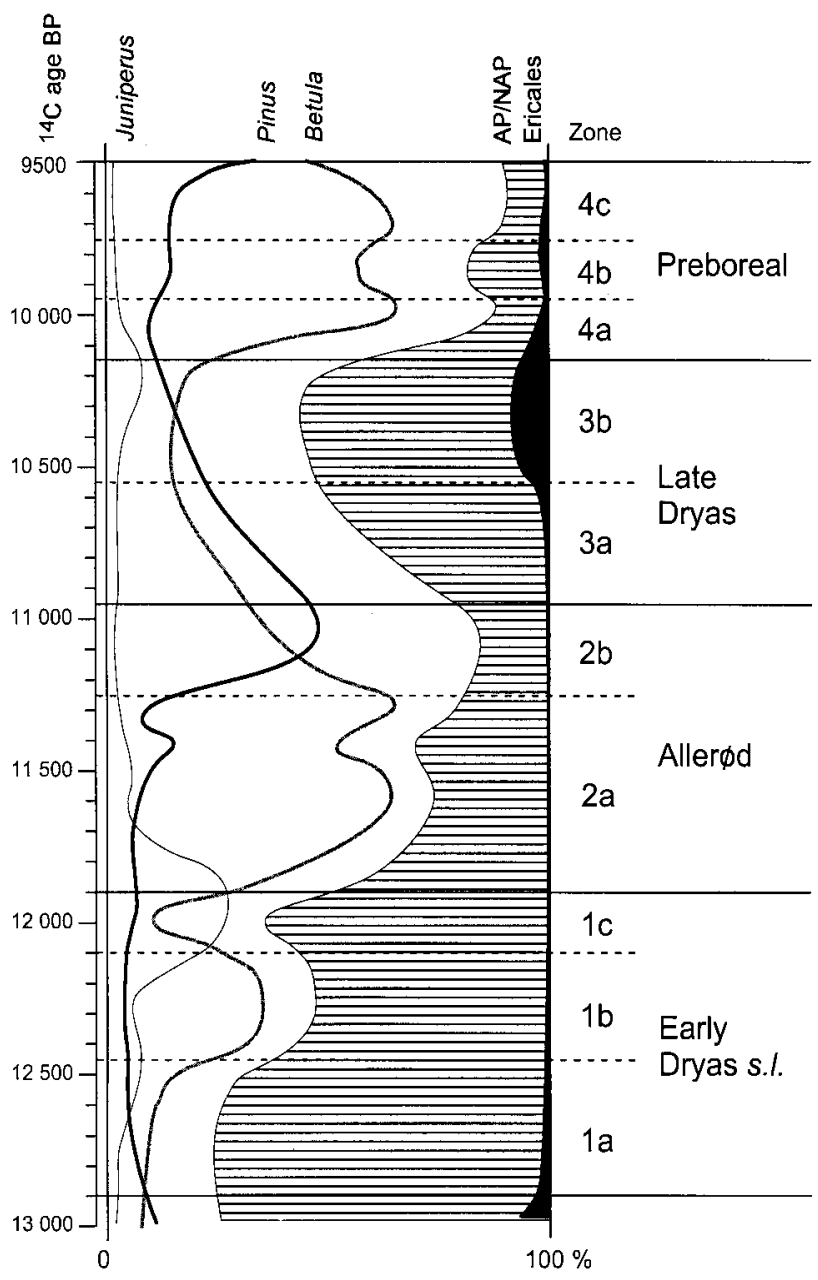

Fig. 2. General vegetation development presented as a schematic percentage pollen diagram against the uncalibrated ${ }^{14} \mathrm{C}$ timescale (after Hoek, 1997b). 
description of biozones, the term 'Late Dryas' is used instead of 'Younger Dryas', which is commonly used to describe the associated chronozone (Hoek, 1997c).

\section{Landscape patterns}

A reconstruction of the landscape that existed in The Netherlands during the Late Glacial is presented in Figure 3. In all of the landscape types, open basins were present in which organic material accumulated. These organic infillings contain the palynological evidence (Fig. 1) that has been used to reconstruct the vegetation history in these areas.

\section{Vegetation patterns}

Iso-pollen maps show the changes in vegetation composition and patterns (Hoek, 1997d). The iso-pollen maps, which reflect the spatial distribution of each pollen taxon, relate to specific time intervals. These time intervals are the pollen-assemblage zones, as shown in Figure 2. For each location, the average values for the specific taxa within the distinguished zones were retrieved from the database. A squared-inverse distance interpolation with a search radius of 20 $\mathrm{km}$, on a grid of $5 \mathrm{~km}$ by $5 \mathrm{~km}$ has been used for the construction of the iso-pollen patterns. The search radius used in the interpolation is in accordance with the possible source area of the regional pollen rain, and thus the interpolated data are supposed to resem-

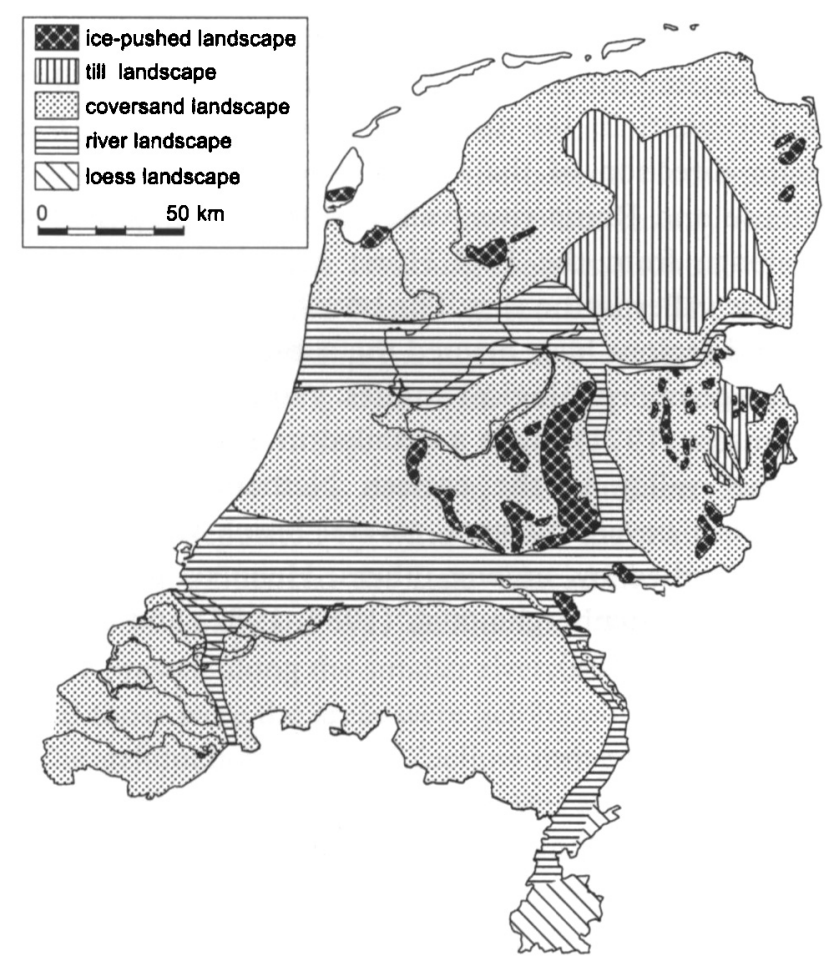

Fig. 3. Reconstruction of the landscape in the Netherlands during the Late Glacial. ble the regional vegetation. A value has been computed for each $5-\mathrm{km}$ grid point; the outcome has automatically been blanked for areas from where no data were available within the search radius. This implies that no extrapolations into areas without data have been made. The data points used in the interpolation are displayed as black dots.

\section{Late Glacial abiotic landscape types}

Five principal landscape types can be distinguished in the Netherlands (Fig. 3). These landscape types can be defined on the basis of differences in genesis and lithology.

\section{The ice-pushed landscape}

This landscape type was initially formed under Saalian glacial conditions. During the Saalian glaciation, half of The Netherlands was covered by the Scandinavian ice sheet, which was responsible for the creation of the elevated topography of the middle and northern Netherlands. Ice-pushed ridges reaching up to approx. $100 \mathrm{~m}$ in the central part to about $20 \mathrm{~m}$ in the northern part of the Netherlands constitute the main relief elements of the landscape. Coarse-grained sandur deposits are present around the ice-pushed ridges (Ruegg, 1977).

During the Weichselian, periglacial slope processes prevailed. The valleys, shaped by incision - due to snow meltwater - into the substratum that was frozen during the Pleniglacial, were partly filled with eolian sands and solifluction deposits. Eolian depositiopn and solifluction smoothed the original landscape during drier and wetter phases, reaspectively, of the Pleniglacial. Deflation on the windward slopes of the hills caused the formation of desert pavements, whereas the leeward sides were covered with finegrained, eolian sands. As the ice-pushed ridges consist of mainly well drained fluvial sands and gravels, only a few wet basins occurred where organic deposits could be preserved.

In the ice-pushed landscape, the near absence of preserved organics and thus of ${ }^{14} \mathrm{C}$-datable material often makes it difficult to differentiate between sediments that were formed during the Pleniglacial, and those during the Late Glacial. It can be concluded from the evidence available that processes of slope formation and eolian processes persisted during the Late Glacial.

At the base of the ice-pushed hills, springs occurred where peats could develop in the Late Glacial (Maarleveld \& Van der Schans, 1961; Verbraeck, 1984). A few pingo remnants occur in the ice-pushed land- 
scape, which have been investigated palynologically and geochemically by Bohncke \& Wijmstra (1988).

Between the ice-pushed ridges, deposition of coversands took place during the Pleniglacial and Late Glacial. Pleniglacial slope deposits and Younger Dryas coversands form the sedimentary bodies in between which Late Glacial organic material has been preserved in the Leuvenumse Beek valley (Polak, 1967; De Gans et al., 1989). Low parabolic dunes, palynologically dated as Younger Dryas, have been described by Maarleveld \& Van der Schans (1961). These dunes formed because some vegetation cover, into which eolian material could be trapped, was present during that time.

\section{The till landscape}

The till region in the northern Netherlands was also formed during the Saalian glaciation, and large parts of the northern Netherlands were covered with glacial tills. During the Late Glacial, these tills formed the substratum that became covered locally by a thin layer of coversand in a gently undulating landscape. The tills consist of a clayey/silty matrix with sand, gravel and boulders, but their heterogeneity and compaction make them are largely impermeable, which leads to relatively high groundwater levels in this area. The main geomorphological features in the till landscape are Pleniglacial pingo remnants, that occur frequently in the northern Netherlands (De Gans, 1982). Pingo remnants have been preserved as circular depressions with or without a distinct rampart. Palynological analyses indicate that the infilling of the depressions began in the Late Glacial (Bølling/Allerød interstadial), supporting the interpretation that they formed during the Pleniglacial (Bohncke et al., 1988). The pingo remnants are mainly filled with organic gyttja or peat. In several pingo remnants, eolian sands were blown into the lakes during the Younger Dryas (Ter Wee, 1966; Bohncke \& Wijmstra, 1988; Bosch, 1990).

In the western part of the till region in particular, coversand deposition took place during the Younger Dryas (De Groot et al., 1987), but there is no evidence that this occurred in the eastern part of the till region at the time (Bosch, 1990).

From the centre of the Drenthe Plateau, several brook valleys developed, forming a radial drainage pattern. The brook valleys dissecting the till landscape have been studied by, among others, De Gans (1982) and De Groot et al. (1987).

\section{The coversand landscape}

Most of the Netherlands Late Glacial landscape was covered with a layer of eolian sands. The so-called 'Older Coversands' have been mainly deposited during the (Late) Pleniglacial and formed a flat undulating topography. The 'Younger Coversands' were deposited during the Late Glacial and Early Holocene and formed a subdued dune topography. Layers of coversand deposited between the Saalian ice-pushed ridges characterise the coversand region in the eastern Netherlands. The coversand region in the southern Netherlands is characterised by a gently undulating topography; the coversand thickness varies from some meters to a few decimetres. In the southwestern part, Early Pleistocene clayey deposits occur at a shallow depth. The presence of the Peel Horst, the Venlo Graben and the RuhrValley Graben resulted in differences in thickness of the coversands in the southeastern part.

Eolian processes were responsible for most of the Late Glacial geomorphology in the coversand area. Organic deposits in this landscape type consist of peats and shallow lacustrine deposits formed in the depressions between coversand ridges (Van der Hammen \&Wijmstra, 1971; Van Geel et al., 1989).

Pingo remnants with a Late Glacial infill in the northeastern coversand region have been described by, among others, Bijlsma \& De Lange (1983) and Van der Woude (1984). Some smaller pingo remnants occur in the southern Netherlands coversand region (Bisschops, 1973; Van Leeuwaarden, 1982; Bisschops et al., 1985; Kasse \& Bohncke, 1992; Hoek \& Joosten, 1995). The main direction of the brook valleys in the northeastern coversand area is towards the Vecht river valley in the north and towards the IJssel river valley in the west. In the southern coversand region, the main direction of the brook valleys is towards the Meuse and Rhine river valley in the north, whereas drainage from the Peel Horst area is towards the Meuse valley in the east. The brook valleys in the coversand regions have formed the subject of several detailed geomorphological studies. Van der Hammen \& Wijmstra (1971) made a detailed investigation of the Dinkel valley in the eastern Netherlands. In the southern coversand area, several brook valleys have been studied by, among others, Heijnens \& Tijssen (1982), Vandenberghe et al. (1984, 1987) and Cleveringa et al. (1988).

\section{The river landscape}

The subsoil of the Netherlands consists mainly of fluvial sediments from the Rhine, Meuse and Scheldt. These rivers formed a series of terraces during the Quaternary as a result of tectonic uplift in the southern Netherlands which, for the Rhine and Meuse, can 
be recognised in the province of Limburg (Van den Berg, 1996). Further to the north-west, only the youngest terraces can be recognised near the surface. The terrace levels that can be distinguished are of Pleniglacial and Late Glacial age. In the central and western Netherlands, however, terraces are covered with Holocene deposits, which become increasingly thick towards the west. Investigation of the Late Glacial fluvial history has therefore been predominantly restricted to the central and south-eastern Netherlands. The river landscape during the Late Glacial has been described by, among others, Van den Broek \& Maarleveld (1963), Berendsen et al. (1995), Kasse et al. (1995) and Huisink (1999).

Discharge, sediment load and, subsequently, river pattern changed during the Late Glacial as a result of climate change. As rivers changed their patterns and morphology between braiding and meandering, the abandoned river channels formed basins where organic deposits could be preserved.

In the second part of the Younger Dryas stadial, from 10,550-10,150 BP, sand was blown out of river floodplains and formed river dunes because eolian material was trapped in the vegetation cover along the valleys on the older terraces. Occasionally, organic deposits in abandoned channels and backswamps were buried under thick layers of eolian sand (Bohncke et al., 1993).

\section{The loess landscape}

In the southernmost part of the Netherlands (southern Limburg), Quaternary river terraces are covered with thick layers of loess. Small areas of loess occur also in a few other places in the central Netherlands. The deposition of the loess took place mainly during the Pleniglacial. The Limburg loess is situated in the northern part of the European loess belt. The transition from coversand in the north to loess in the south is a result of along-track size sorting by northerly winds (Schwan, 1986).

Although the loess cover in the southern Netherlands was deposited by wind action, the main mechanism that influenced the Late Glacial morphology in the loess landscape was gelifluction. Steep gradients were present along the smaller rivers and brook valleys, and those were the areas were gelifluction could occur. The gelifluction material (colluvium) partly filled the smaller river and brook valleys in this area. In some river valleys, peat formation occurred during the Late Glacial and Early Holocene (Janssen, 1960; Kuyl, 1980; Van den Broek, 1981), indicating that slope processes had ceased, at least locally. These sparse peat deposits form the palynological archive for this region.

\section{Landscape/vegetation interactions}

Climatically driven geomorphological processes, and the rates of operation of those processes, varied between the various landscape types. This must partly have been caused by differences in vegetation cover, which in turn are also determined by the abiotic landscape. This points towards a whole range of complex feedback mechanisms (Hoek, in prep.), but essentially climate and abiotic landscape determine the vegetation patterns. A selection of distribution maps for four specific taxa through time are presented in Figures 4-7. These maps illustrate the influence of the abiotic landscape on the vegetation patterns.

\section{APpatterns}

Within the group of arboreal pollen (AP), the main taxa are Betula and Pinus; to a lesser extent, Salix and Populus occur. The AP percentages are an indication of forest density during the Late Glacial and Early Holocene, with the highest values usually occurring during warmer time intervals. Low AP percentages are indicative of more herbaceous, colder vegetation types. The AP percentages can, however, not be used as a temperature proxy (Van Geel, 1996). Moreover, an absolute value for the forest density based on AP percentages is difficult to establish, though relative changes in AP percentage may indicate changes in forest density. As a guideline, $50 \% \mathrm{AP}$ can be taken to imply the occurrence of forest during the investigated time-span (Zagwijn, 1989).

Iso-pollen maps for AP percentages during several time-windows were constructed based on approx. 250 pollen diagrams. These maps, presented in Figure 4, show the distribution of AP percentages in time and space. AP percentages below $50 \%$ during the earliest part of the Late Glacial suggest that herbaceous communities then covered large parts of the Netherlands, whereas higher percentage values later in the Late Glacial suggest the presence of forests.

\section{Pinus patterns}

Pinus sylvestris currently grows on light, non-calcareous freely drained soils (Carlisle \& Brown, 1968). For the Late Glacial, Huntley \& Birks (1983) showed that Pinus migrated in a westward direction across this region at a maximum rate of at least $1.5 \mathrm{~km} /$ year, values above $20 \%$ probably reflecting local occurrence. Pinus migrated into the Netherlands at the boundary between subzone $2 \mathrm{a}$ and $2 \mathrm{~b}$, dated at around $11,250 \mathrm{BP}$ (Hoek, 1997b), with the Rhine valley probably forming the major immigration pathway (Fig. 5). The mi- 

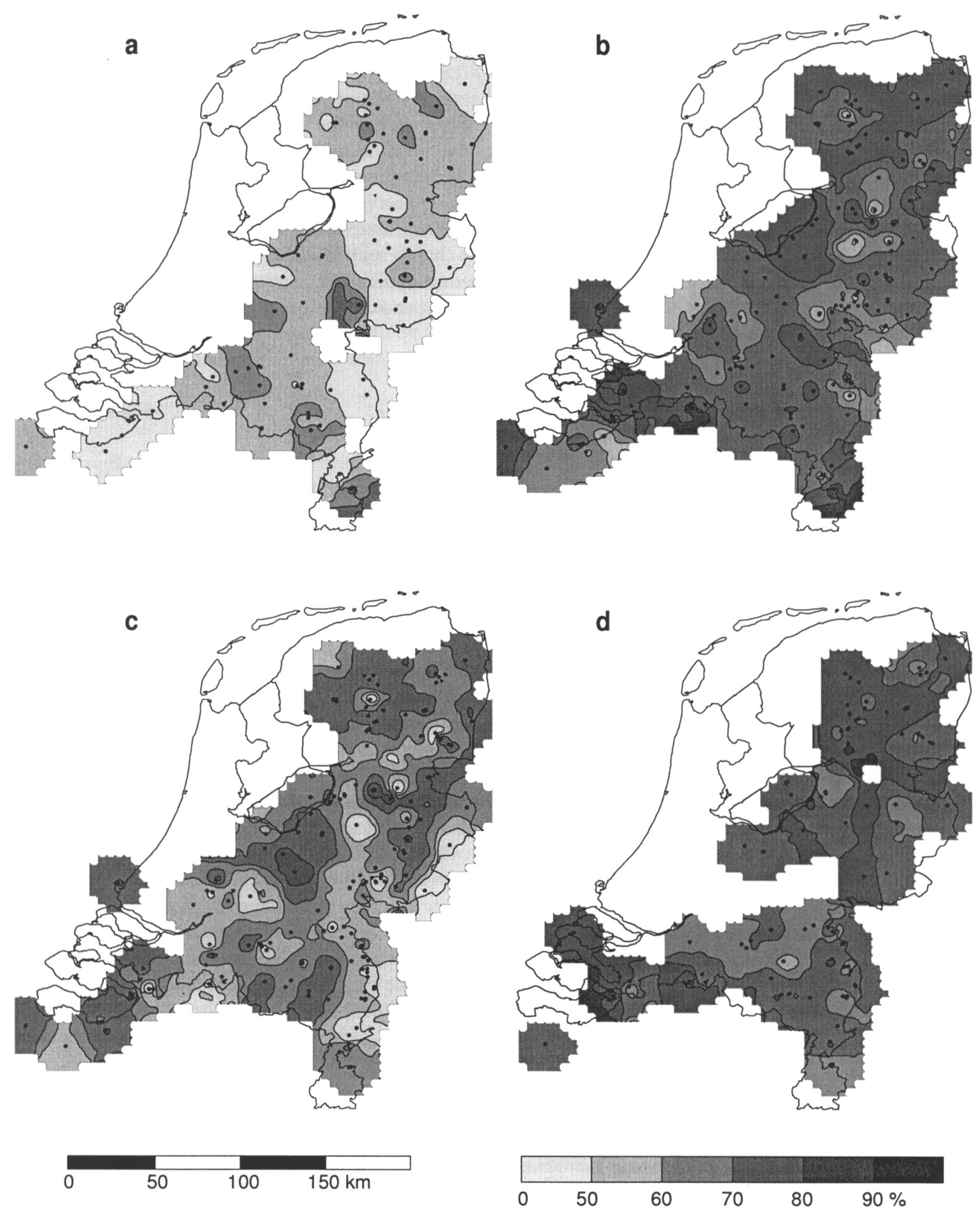

Fig. 4. Iso-pollen maps for AP percentages in the Netherlands.

a: Early Dryas s.l. (zone 1:12,900-1 1,900 BP). AP percentages below 50\% suggest that herbaceous communities covered large parts of the Netherlands.

b: Allerød (zone 2: 11,900-10,950 BP). AP increased to values above $70 \%$, indicating that forests closed. In the river region, vegetation had a supposedly more open character.

c: Late Dryas (zone 3: 10,950-10,150 BP). The forest was less dense than during the preceding zone, particularly in the river region, which might be related to the larger river discharges during this time interval. The more elevated areas show higher AP percentages.

$\mathrm{d}$ : (zone 4: 10,150-9,500 BP). AP percentages increased again to values generally above $70 \%$. Lower AP values in the southern Netherlands coversand region might be a result of the presence of freshly deposited coversands. 

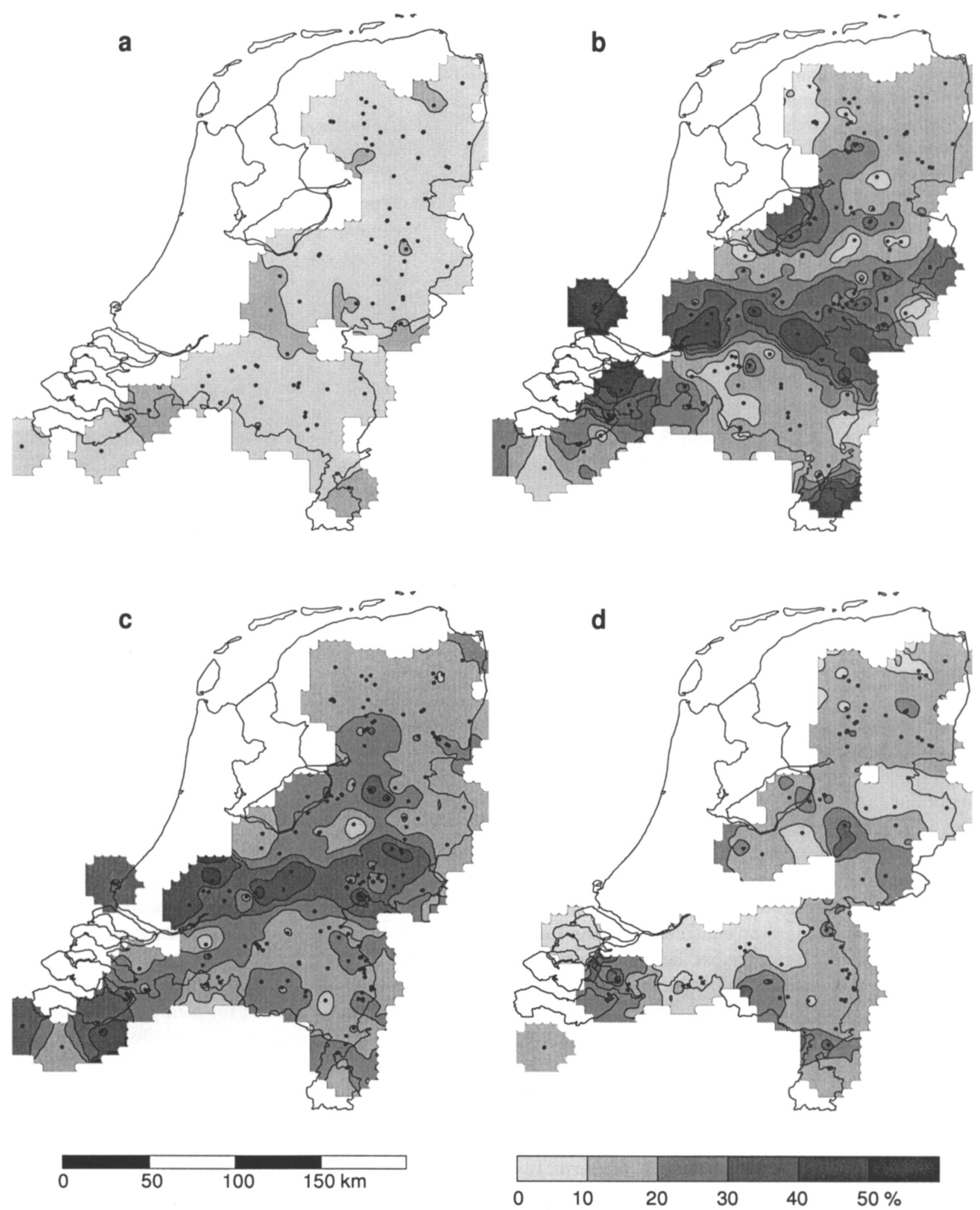

Fig. 5. Iso-pollen maps for Pinus percentages in the Netherlands.

a: Early Dryas s.l. (zone 1:12,900-11,900 BP). Pinus pollen was present in values less than $20 \%$, which can be considered as an indication of long-distance transport.

b: Allerød (zone 2: 11,900-10,950 BP). The highest values of Pinus, up to $75 \%$ locally, are recorded in the central Netherlands river region. The lowest values are recorded in the eastern part of the southern Netherlands coversand region.

c: Late Dryas (zone 3: 10,950-10,150 BP). The average percentages decrease to between $40 \%$ and $60 \%$. Pinus values are the highest in the central Netherlands river region.

d: Preboreal (zone 4: 10,150-9,500 BP). Pinus has been recorded with percentages around 30\%, indicating that Pinus was present though in low amounts. 
gration process did not occur along a closed front but by outposts, according to the ecotone concept, with patches of trees migrating and expanding in time. Bos (1998) described Pinus macrofossils from the southern Netherlands dated around 11,500 BP, indicating that pine already was locally present there.

The highest percentages of Pinus are found in the river region, suggesting that pine actually inhabited the river valleys. As Pinus sylvestris is presently associated with drier sites, it is unlikely that pine was growing on the river valley floors (van Leeuwaarden, 1982) but largely colonised the higher terraces and valley slopes. Ellenberg (1963), however, described pine growing under exceptional conditions on river floors, indicating that occasional stands of pine may have been present in those locations. The high percentages of Pinus in zones 2 and 3 in the central Netherlands river region may, on the other hand, also be partly a result of a more open herbaceous vegetation type, as indicated by the low AP values in Figures $4 \mathrm{~b}$ and $4 \mathrm{c}$, with Pinus being over-represented as a result of long-distance transport. In the Late Preboreal, from about 9,500 BP onward, Pinus re-colonised the Netherlands.

\section{Funiperus patterns}

The growth of funiperus communis is favoured by a bare sandy substratum where eolian activity is limited. Funiperus is present in the Netherlands from the start of the Late Glacial, migration occurring rapidly, as birds spread the fruits. Funiperus is considered to form a shrub belt in front of the Betula forest line on dry soils (van der Hammen, 1951).

Funiperus, recorded in $81 \%$ of the diagrams in the database, was an important constituent of the Late Glacial vegetation. Funiperus has been recorded in $74 \%$ of the pollen diagrams from the first part of the Late Glacial: zones 1 and 2 (12,900-10,950 BP). During the Late Dryas and Preboreal zones 3 and 4 (10,950-9,500 BP), Funiperus pollen has been recorded less frequently, in $64 \%$ and $61 \%$ of the pollen diagrams, respectively. The highest average values, reaching $15 \%$, are found in subzone 1c $(12,100-11,900$ $\mathrm{BP}$ ), where $85 \%$ of the diagrams contain funiperus. In the very beginning of subzone $2 \mathrm{a}(11,900-11,500 \mathrm{BP})$ high values are also recorded.

The ice-pushed and coversand areas consist of sandy, well-drained sediments. It is therefore likely that funiperus had a preference for these regions during the course of the Late Glacial, including the more forested zone 2 (Fig. 6). The lowest percentages in zone 2 are recorded in the river valleys and the northern Netherlands till region, which are areas with high- er groundwater levels and a less sandy substratum. In subzone $1 \mathrm{c}$ and zone 3, eolian activity in the coversand regions limited the occurrence of funiperus. The coversand ridges and river dunes formed in these periods did, however, create a new habitat for funiperus. It can be concluded from the maps that juniper changed its most preferred position from the icepushed ridges in the early Late Glacial towards the coversand regions at the end of the Late Glacial and beginning of the Holocene.

\section{Ericales patterns}

Ericales are calcifuge herbs that flourish on leached soils. Increasing climatic oceanicity and soil formation commonly favour the distribution of Ericales. The main constituent of the group of Ericales during the Late Glacial is Empetrum nigrum, and hence the patterns show distributions that are largely those for Empetrum (Hoek, 1997d). Later in the Holocene, Calluna vulgaris and Erica tetralix became more prominent constituents (Huntley \& Birks, 1983). The occurrence of Empetrum nigrum has often been used as an indicator of increased oceanicity, reflecting higher precipitation rates or more extensive snow cover (Brown, 1971). At present, an abundance of Ericales indicates a low nutrient availability and acid soils, a situation occurring already in the till region during the time-span under investigation.

Ericales are present in most (92\%) diagrams in the database, in values ranging between 0 and $15 \%$, with locally high values of $30 \%$. In zone $1(12,900-11,900$ $\mathrm{BP})$ and $2(11,900-10,950 \mathrm{BP})$ they occur in 82 and $81 \%$ of the diagrams, respectively. In zone $3(10,950-$ $10,150 \mathrm{BP})$, Ericales pollen has been recorded in $91 \%$ of the pollen diagrams in the database. In zone 4 $(10,150-9,500 \mathrm{BP})$, Ericales are recorded in $86 \%$ of the diagrams with mostly values below $5 \%$.

The distribution pattern for zone 3 shows that the high values are linked to the poorly drained and leached soils in tills situated in the northern Netherlands (Fig. 7c). The higher percentages outside the area of Saalian till deposits are mostly related to sites on a clayey substratum at shallow depth.

\section{Discussion and conclusions}

At the regional scale, climate influences both geomorphology (rates of operation of processes) and vegetation. Above this, there are clear indications about the interaction between vegetation and geomorphology. The Younger Dryas climate change, for instance, caused the formation of river dunes and coversands, indicating that the vegetation cover was relatively 

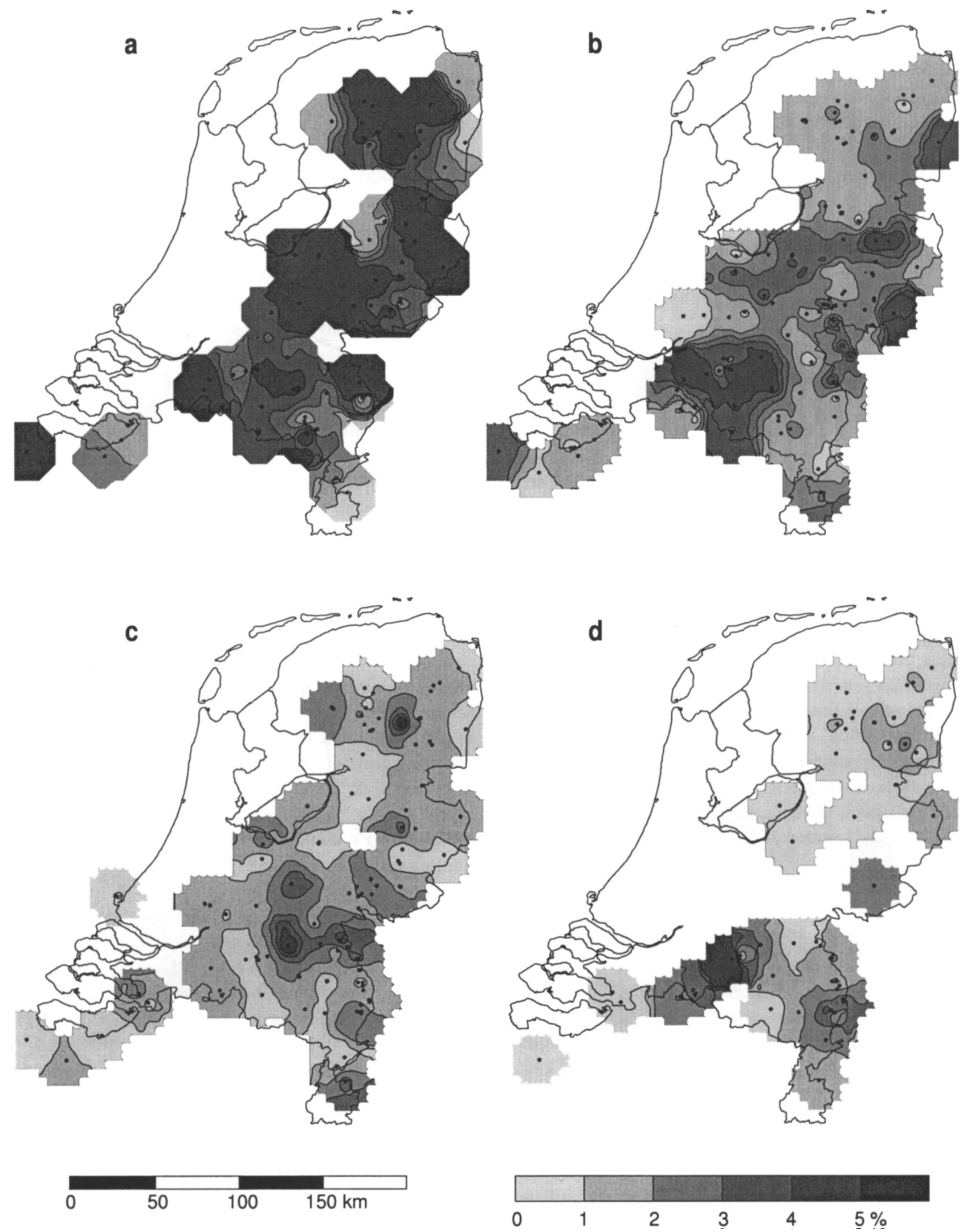

Fig. 6. Iso-pollen maps for Funiperus percentages in the Netherlands.

a: Early Dryas s.l. (zone 1:12,900-11,900 BP). A wide spread distribution of funiperus over the Netherlands can be seen.

b: Allerød (zone 2: 11,900-10,950 BP). The highest percentages can be seen in the coversand areas, while low values occur in the central Netherlands river region. The till region was almost completely abandoned by funiperus.

c: Late Dryas (zone 3: 10,950-10,150 BP). The highest percentages (5\%) might be related to the presence of river dunes in the Meuse valley. $\mathrm{d}$ : Preboreal (zone 4: 10,150-9,500 BP). Juniperus was present in low values around $2 \%$, except for some local occurrences in the coversand region. 

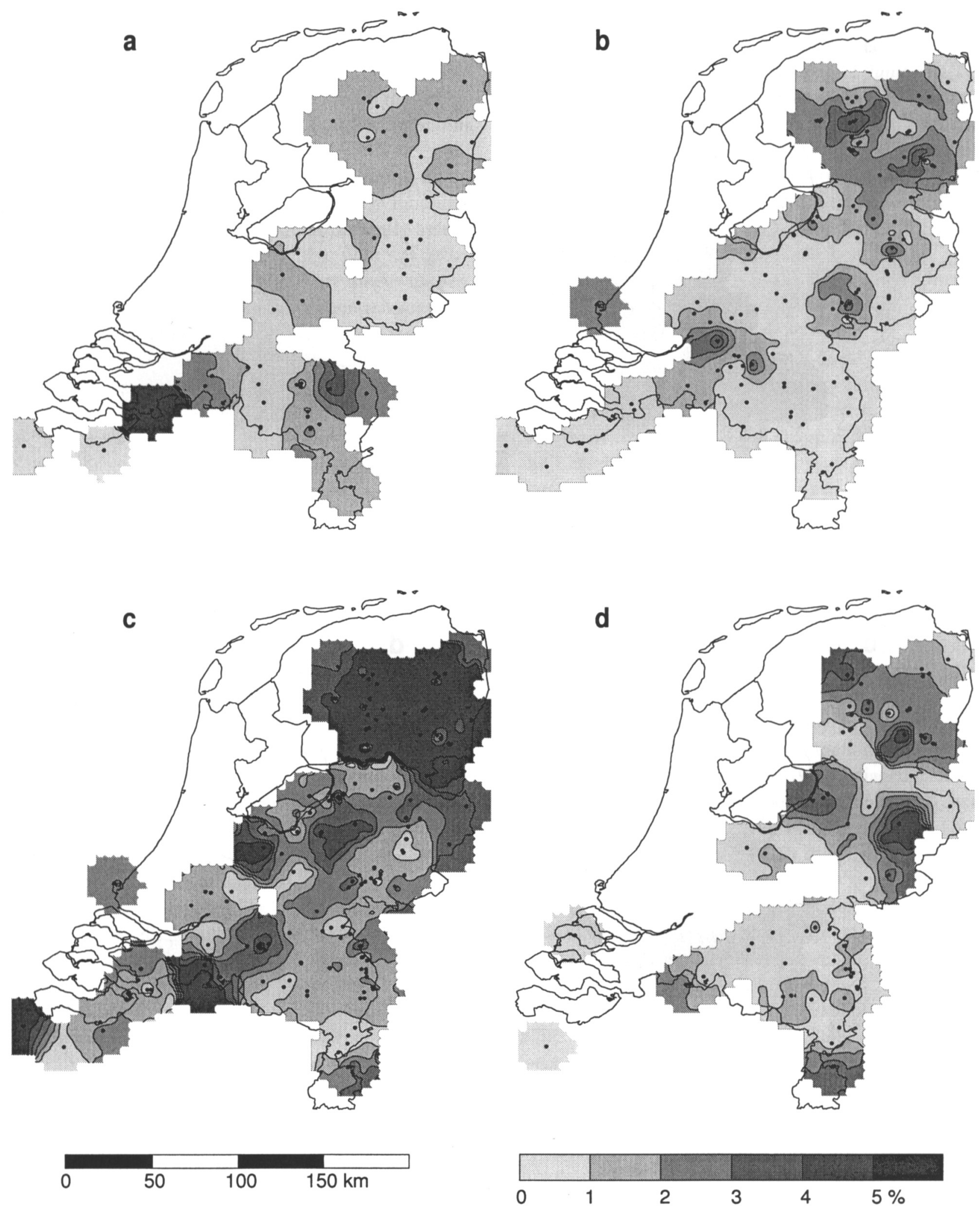

Fig. 7. Iso-pollen maps for Ericales percentages in the Netherlands.

$a$ : Early Dryas s.l. (zone 1:12,900-11,900 BP). Ericales values were below $2 \%$ in the Netherlands. The locally higher values are a result of reworking from older deposits.

b: Allerød (zone 2: 11,900-10,950 BP). Ericales values were generally below 2\%, but higher values can be seen in the northern Netherlands in particular.

c: Late Dryas (zone 3: 10,950-10,150 BP). Values over 15\% are found in the northern Netherlands till region. In both the ice-pushed region of the central Netherlands and the southwestern part of the Netherlands, values above $5 \%$ occur, while in the coversand and river region values remain below $5 \%$.

d: Preboreal (zone 4: 10,150-9,500 BP). In the northern Netherlands, some higher values can be seen, although values remain below $10 \%$. 
open. This abiotic evidence supports the palynological indications for a change from open birch/pine woods towards a park tundra with scattered trees and shrubs. The geomorphology influenced the vegetation in a range of ways, and this occurred at both a regional and, more often, a local scale. The vegetation also influenced the geomorphology, again both regionally and locally. A good example is the building of dunes as a result of eolian material being trapped by isolated patches of vegetation. Undoubtedly, both phenomena are closely related. A combined vegetational and geomorphological study has nevertheless, rarely been undertaken in previous investigations. Yet, the comparison of vegetation patterns and maps of the abiotic landscape can provide information about their relationships.

In essence, climate and abiotic landscape determine the vegetation patterns. The changes of vegetation with time can be considered as changes in vegetation patterns, which varied within each abiotic landscape type. Not only the climate and the abiotic landscape influenced the vegetation development, however. Light-demanding taxa gradually disappeared during the glacial/interglacial transition as the vegetation expanded. Heliophilous taxa like Hippophaë rhamnoides, Ephedra distachya, Artemisia, Chenopodiaceae, Cruciferae, Helianthemum, Plantago, Rumex and Sanguisorba minor were progressively eliminated as the density of the vegetation cover increased. During the Late Glacial, Salix was replaced by Betula, which also requires moist soil conditions but formed relatively closed forests. On drier substrates, funiperus was shaded out by Pinus. Heliophilous taxa almost disappeared during the Early Holocene as a result of the development of dense forests. Not only developing forests but also more humic soils were unfavourable for heliophilous taxa like Hippophaë rhamnoides, Ephedra distachya, Helianthemum and Armeria mariti$m a$. The coversand and till regions were probably not rich enough in nutrients for the growth of taxa like Filipendula ulmaria, which require humic soils.

Iso-pollen patterns for selected time-windows of the Late Glacial in the Netherlands demonstrate that climate was not the only influence on vegetation. The effects of climate can certainly be seen in the largescale vegetation sequence (Fig. 2), and changes in climate caused marked changes in vegetation as reflected in the changes of iso-pollen patterns through time. The abiotic landscape components also exited an influence on the vegetation development, however.

The arboreal pollen (AP) patterns for various zones within the Late Glacial and Early Holocene show not only the influence of the climate as reflected in the increasing values through time, but also a relationship with the abiotic landscape. After an increase from the early Late Glacial to the Allerød (Fig. 4a-b), lower AP percentages can be recognised for the Late Dryas zone (Fig. 4c), particularly in the coversand and river region. In these areas, large-scale eolian processes were active and coversand ridges and riverdunes were formed.

Specific maps, such as those for Pinus and Funiperus, lead to interesting conclusions about migrational patterns that are related to the Late Glacial landscape. It appeared that pine migrated during the Allerød (around 11,250 BP) into the Netherlands along the Rhine corridor. High values of Pinus can be found specifically in the central Netherlands river region (Fig. 5b). Pine supposedly inhabited the borders of the higher fluvial terraces and colonised the uplands from there. Juniper changed its preferred location from the ice-pushed area in the early Late Glacial towards the southern coversand region at the end of the Late Glacial and beginning of the Holocene.

Adopting a direct relationship between vegetation and climate, for instance by using fossil pollen assemblages and a modern-analogue transfer function to reconstruct paleoclimate, can easily yield erroneous results. This can be demonstrated by, for instance, the increase in Empetrum nigrum percentages during zone $3(10,950-10,150 \mathrm{BP})$, particularly in the till region (Fig. 7c). The increase in percentage may have been a result of lower temperatures, in combination with an increase in precipitation and snow cover during this time interval, but the distribution pattern is evidently also strongly influenced by the abiotic landscape. An abundance of Ericales during zone 3 is restricted to a specific region, while the Younger Dryas climatic change associated with this biozone is supposed to have influenced a much larger area. This implies that one has to be cautious with the use of transfer functions in paleoclimate reconstruction.

To conclude, the influence of the abiotic landscape on vegetation has to be taken into account, when interpreting climate/vegetation relationships. By using a paleogeographical approach, the vegetation patterns and changes in these patterns can be compared with geological or geomorphological maps. It appears that the influence of the abiotic landscape factors on vegetation patterns can be visualized in many instances. This approach requires, however, a dense network of well-dated palynological sites in an area with a wellknown geology and geomorphology, such as the $\mathrm{Ne}$ therlands.

\section{Acknowledgements}

Prof. Dr. W.H. Zagwijn, Dr. S.J.P. Bohncke, Dr. B. van Geel and Dr. C. Kasse are acknowledged for their 
valuable comments on the manuscript. I am especially grateful to Prof. Dr. M.J.C. Walker for his valuable comments and for correcting the English. This study forms part of the project: Palaeogeography of Lateglacial vegetations: analysis in time and space. The aim of the project was to reconstruct the Late Glacial vegetation in the northwest European lowland in relation to climate and abiotic landscape components. The project was sponsored by The Netherlands Organisation for Scientific Research (N.W.O.- G.O.A.) and was incorporated in the research program of The Netherlands Centre for Geo-ecological Research (I.C.G.). Supervisor of the project was Prof. Dr.W.H. Zagwijn.

\section{References}

Berendsen, H., Hoek, W. \& Schorn, E., 1995. Late Weichselian and Holocene river channel changes of the rivers Rhine and Meuse in the Netherlands (Land van Maas en Waal). Paläoklimaforschung 14: 151-171.

Bijlsma, S. \& De Lange, G.W., 1983. Geology, palynology and age of a pingo remnant near Daarle, province of Overijssel, The Netherlands. Geologie en Mijnbouw 62: 563-568.

Bisschops, J.H., 1973. Toelichtingen bij de Geologische kaart van Nederland 1:50.000, Eindhoven Oost (51 O). Rijks Geologische Dienst (Haarlem): $132 \mathrm{pp}$.

Bisschops, J.H., Broertjes, J.P. \& Dobma, W., 1985. Toelichtingen bij de Geologische kaart van Nederland 1:50.000, Eindhoven West (51 W). Rijks Geologische Dienst (Haarlem): 216 pp.

Bohncke, S.J.P., 1993. Lateglacial environmental changes in the Netherlands: spatial and temporal patterns. Quaternary Science Reviews 12: 707-718.

Bohncke, S., Vandenberghe, J. \& Huijzer, A.S., 1993. Periglacial palaeoenvironment during the Lateglacial in the Maas valley. Geologie en Mijnbouw 72: 193-210.

Bohncke, S.J.P. \& Wijmstra, T.A., 1988. Reconstruction of LateGlacial lake-level fluctuations in The Netherlands based on palaeobotanical analyses, geochemical results and pollen-density data. Boreas 17: 403-425.

Bohncke, S.J.P., Wijmstra, T.A., Van der Woude, J. \& Sohl, H., 1988. The Late-Glacial infill of three lake successions in The Netherlands: regional vegetational history in relation to NW European vegetational developments. Boreas 17: 385-402.

Bos, J.A.A, 1998. Aspects of the Lateglacial-Early Holocene vegetation development in western Europe. Palynological and palaeobotanical investigations in Brabant (The Netherlands) and Hessen (Germany). Ph.D. thesis Utrecht University: $240 \mathrm{pp}$.

Bosch, J.H.A., 1990. Toelichtingen bij de Geologische kaart van Nederland 1:50.000, Assen West (12 W) en Assen Oost (12 O). Rijks Geologische Dienst (Haarlem): 188 pp.

Brown, A.P., 1971. The empetrum pollen record as a climatic indicator in the Late Weichselian and Early Flandrian of the British Isles. New Phytologist 70: 841-849 .

Carlisle A. \& Brown, A.H.F., 1968. Biological flora of the British Isles - Pinus sylvestris L. Journal of Ecology 56: 269-307.

Cleveringa, P., De Gans, W., Huybrechts, W. \& Verbruggen, C., 1988. Outline of river adjustments in small river basins in Belgium and the Netherlands since the Upper Pleniglacial. In: Lang, G. \& Schluchter, Ch. (eds.): Lake, mire and river environments. Balkema (Rotterdam): 123-132.
De Gans, W., 1982. Location, age and origin of pingo remnants in the Drentsche Aa valley area (The Netherlands). Geologie en Mijnbouw 61: 147-158.

De Gans, W., Cleveringa, P. \& Jagerman, R., 1989. Late Weichselian and Holocene sedimentary history of the Leuvenumse beek valley (the Netherlands). Geologie en Mijnbouw 68: 161- 174.

De Groot, T.A.M, Van Adrichem Boogaert, H.A., Fischer, M.M., Klijnstra, B., Van Montfrans, H.M., Uil, H., Ter Wee, M.W., Van Weperen, M.J. \& Zandstra, J.G., 1987. Toelichtingen bij de Geologische kaart van Nederland 1:50.000, Heerenveen West (11 W) en Heerenveen Oost $(110)$. Rijks Geologische Dienst (Haarlem): $251 \mathrm{pp}$.

Ellenberg, H., 1963. Vegetation Mitteleuropas mit den Alpen in ökologischer Sicht. Ulmer (Stuttgart): 943 pp.

Heijnens, M.H.L.G. \& Tijssen , J.M., 1982. The influence of the development of a Weichselian coversand ridge in the drainage of a river valley in Noord-Brabant (the Netherlands); a geomorphological and palynological study. Geologie en Mijnbouw 61: 191-199.

Hoek, W.Z., 1997a. Patterns of Late Glacial vegetation in The Netherlands. Eiszeitalter und Gegenwart 47: 78-88.

Hoek, W.Z., 1997b. Late-Glacial and early Holocene climatic events and chronology of vegetation development in the Netherlands. Vegetation History and Archaeobotany 6: 197-213.

Hoek, W.Z., 1997c. Palaeogeography of Lateglacial vegetations aspects of Lateglacial and Early Holocene vegetation, abiotic landscape, and climate in The Netherlands. Netherlands Geographical Studies $230: 160 \mathrm{pp}$.

Hoek, W.Z., 1997d. Atlas to Palaeogeography of Lateglacial vegetations - maps of Lateglacial and Early Holocene landscape and vegetation in The Netherlands, with an extensive review of available palynological data. Netherlands Geographical Studies 231:176 pp.

Hoek, W.Z. \& Joosten, J.H.J., 1995. Pingo-ruïnes en kalkgyttja in het Weerterbos. Natuur Historisch Maandblad 84: 234-241.

Huisink, M., 1999. Changing river styles in response to climate change. Examples from the Maas and Vecht during the Weichselian Pleni- and Lateglacial. Ph.D. thesis Vrije Universiteit Amsterdam: $127 \mathrm{pp}$.

Huntley, B. \& Birks, H.J.B., 1983. An atlas of past and present pollen maps for Europe: 0-13,000 years ago. Cambridge University Press (Cambridge): $667 \mathrm{pp}$.

Janssen, C.R. ,1960. On the Lateglacial and Postglacial vegetation of South Limburg. Ph.D. thesis Utrecht University / N-Holland Publishing Company (Amsterdam): 112 pp.

Kasse, K. \& Bohncke, S., 1992. Weichselian upper Pleniglacial aeolian and ice-cored morphology in the southern Netherlands (Noord-Brabant, Groote Peel). Permafrost and Periglacial Processes 3: 327-342.

Kasse, K., Vandenberghe, J. \& Bohncke, S., 1995. Climatic change and fluvial dynamics of the Maas during the Late Weichselian and Early Holocene. Paläoklimaforschung 14: 123-150.

Kuyl, O.S., 1980. Toelichtingen bij de Geologische kaart van Nederland 1:50.000, Heerlen (62). Rijks Geologische Dienst (Haarlem): 206 pp.

Maarleveld, G.C. \& Van der Schans, R.P.H.P., 1961. De dekzandmorfologie van de Gelderse Vallei. Tijdschrift van het Koninklijk Nederlands Aardrijkskundig Genootschap 78: 22-34.

Polak, B., 1967. Palynology of the peat deposits alongside the Leuvenum Brook. Acta Botanica Neerlandica 16: 62-70.

Ruegg, G.H.J., 1977. Features of Middle Pleistocene sandur deposits in The Netherlands. Geologie en Mijnbouw 56: 5-24.

Schwan, J., 1986. The origin of horizontal alternating bedding in Weichselian aeolian sands in northwestern Europe. Sedimentary Geology 49: 73-108. 
Ter Wee, M.W., 1966. Toelichtingen bij de Geologische kaart van Nederland 1:50.000, Steenwijk Oost (16 O). Geologische Stichting, Afdeling Geologische Dienst (Haarlem): $106 \mathrm{pp}$.

Vandenberghe, J., Paris, P., Kasse, C., Gouman, M. \& Beyens, L., 1984. Palaeomorphological and -botanical evolution of small lowland valleys - a case study of the Mark valley in Northern Belgium. Catena 11: 229-238.

Vandenberghe, J., Bohncke, S., Lammers, W. \& Zilverberg, L., 1987. Geomorphology and palaeoecology of the Mark valley (southern Netherlands): geomorphological valley development during the Weichselian and Holocene. Boreas 16: 55-67.

Van den Berg, M.W., 1996. Fluvial sequences of the Maas, a $10 \mathrm{Ma}$ record of neotectonics and climate change at various time-scales. Ph.D. thesis Agricultural University Wageningen: $181 \mathrm{pp}$.

Van den Broek, J.M.M., 1981. Ouderdom en vorming van de dalopvulling van de Roode Beek tussen Schinveld en Sittard. Boor en Spade 20: 124-144.

Van den Broek, J.M.M. \& Maarleveld, G.C., 1963. The Late-Pleistocene terrace deposits of the Meuse. Mededelingen van de Geologische Stichting 16: 13-24.

Van der Hammen, Th., 1951. Late-Glacial flora and periglacial phenomena in The Netherlands. Ph.D. thesis Leiden University / Leidse Geologische Mededelingen 17: 71-183.

Van der Hammen, Th. \& Wijmstra, T.A. (eds.), 1971. The Upper
Quaternary of the Dinkel valley. Mededelingen Rijks Geologische Dienst 22: 55-214.

Van der Woude, J.D., 1984. Gradual pollen zone transition from Allerød to Younger Dryas in an eastern netherlands' lake fill. Geologie en Mijnbouw 63: 377-380.

Van Geel, B., 1996. Factors influencing changing AP/NAP ratios in NW-Europe during the Late-Glacial period. Il Quaternario 9: 599-604.

Van Geel, B., Coope, G.R. \& Van der Hammen, Th., 1989. Palaeoecology and stratigraphy of the Lateglacial type section at Usselo (The Netherlands). Review of Palaeobotany and Palynology 39: 25-129.

Van Leeuwaarden, W., 1982. Palynological and macropalaeobotanical studies in the development of the vegetation mosaic in eastern Noord-Brabant (The Netherlands) during Late-Glacial and early Holocene times. Ph.D. thesis Rijksuniversiteit Utrecht: 203 $\mathrm{pp}$

Verbraeck, A., 1984. Toelichtingen bij de Geologische kaart van Nederland 1:50.000, Tiel West (39 W) en Tiel Oost (39 O). Rijks Geologische Dienst (Haarlem): 335 pp.

Zagwijn, W.H., 1989, Vegetation and climate during warmer intervals in the Late Pleistocene of western and central Europe. Quaternary International 3/4: 57-67. 